\title{
Phylogenetic Placement of Sarcina ventriculi and Sarcina maxima within Group I Clostridium, a Possible Problem for Future Revision of the Genus Clostridium
}

\author{
Request for an Opinion
}

\author{
A. WILLEMS* AND M. D. COLLINS \\ Microbiology Department, Reading Laboratory, Institute of Food Research, \\ Earley Gate, Reading RG6 2EF, United Kingdom
}

\begin{abstract}
The 16 S rRNA gene sequences of Sarcina ventriculi DSM $286^{\mathrm{T}}$ (T = type strain) and Sarcina maxima DSM $3^{316}{ }^{\mathrm{T}}$ were determined. Phylogenetic analysis revealed that these two species are closely related to each other and belong to group I Clostridium (sensu Johnson and Francis). The implications of these phylogenetic findings for future revision of the genus Clostridium are discussed.
\end{abstract}

In 1842 Goodsir described some bundle-shaped organisms observed in the stomach fluid of a patient with digestive tract problems and named these organisms Sarcina ventriculi (12). This obligately anaerobic microorganism was first cultured by Beijerinck $(1,2)$ and has since been isolated from human and animal stomach contents and feces, soil, and the surfaces of cereal seeds (5). After the original description of $S$. ventriculi, many other mostly aerobic, packet-forming cocci were assigned to the genus Sarcina as separate species. The morphological criterion of packet formation, however, proved to be unsuitable for genus delineation as studies in the 1960s to 1970 s revealed major phenotypic heterogeneity within the genus. Most Sarcina species have now been placed in other genera (i.e., the genus Micrococcus for some aerobic nonsporing species; the genus Sporosarcina for aerobic sporing species; the genus Methanosarcina for anaerobic methane fermenters; and the genus Halococcus for obligate halophiles [3, 4]), and currently only two species, $S$. ventriculi and Sarcina maxima, are retained in the genus Sarcina (5). Studies in which Fox et al. (11) used 16S rRNA oligonucleotide cataloging revealed a possible phylogenetic affinity between $S$. ventriculi and some species of the anaerobic spore-forming genus Clostridium $\left(S_{\mathrm{AB}}\right.$ [see reference 10 for definition] with Clostridium butyricum [the type species], Clostridium scatologenes, and Clostridium pasteurianum, 0.5 to 0.65 ). Oligonucleotide cataloging has in recent years been largely superseded by complete or partial $16 \mathrm{~S}$ rRNA (or rRNA gene) sequencing. Complete (or nearly complete) sequences provide far more precision for determining phylogenetic relationships (20). A large number of clostridial 16S rRNA sequences have been published in recent years $(15,17,18)$, and these sequences now make it possible to determine more precisely the phylogenetic affinities of the sarcinas. In this paper we describe the $16 \mathrm{~S}$ rRNA gene sequences of the type strains of $S$. ventriculi and $S$. maxima and the results of a comprehensive phylogenetic analysis of these organisms and the clostridia.

$S$. ventriculi DSM $286^{\mathrm{T}}(\mathrm{T}=$ type strain) and $S$. maxima DSM $316^{\mathrm{T}}$ were grown anaerobically in Sarcina broth $(5 \mathrm{~g}$ of

\footnotetext{
* Corresponding author. Mailing address: Department of Microbiology, Institute of Food Research, Earley Gate, Whiteknights Road, Reading RG6 2EF, Berkshire, United Kingdom. Phone: 44734 357224. Fax: 44734 267917. Electronic mail address: willems@arcb. afrc.ac.uk.
}

peptone, $5 \mathrm{~g}$ of yeast extract, $30 \mathrm{~g}$ of glucose, 1 liter of $\mathrm{H}_{2} \mathrm{O} ; \mathrm{pH}$ 6.0) at $37^{\circ} \mathrm{C}$, and chromosomal DNAs were prepared as described by Lawson et al. (14). The 16S rRNA genes were amplified by a PCR, purified, and sequenced directly as described previously (19). The sequences which we determined were aligned with sequences of reference organisms obtained from the EMBL data library by using the PILEUP, PRETTY, and UGLY programs of the Genetics Computer Group Sequence Analysis package (7) and a VAX computer. A continuous stretch of 1,343 bases was used in the analysis. Distances were calculated by using the DNADIST program of the Phylogeny Inference package (9), and a bootstrapped phylo-

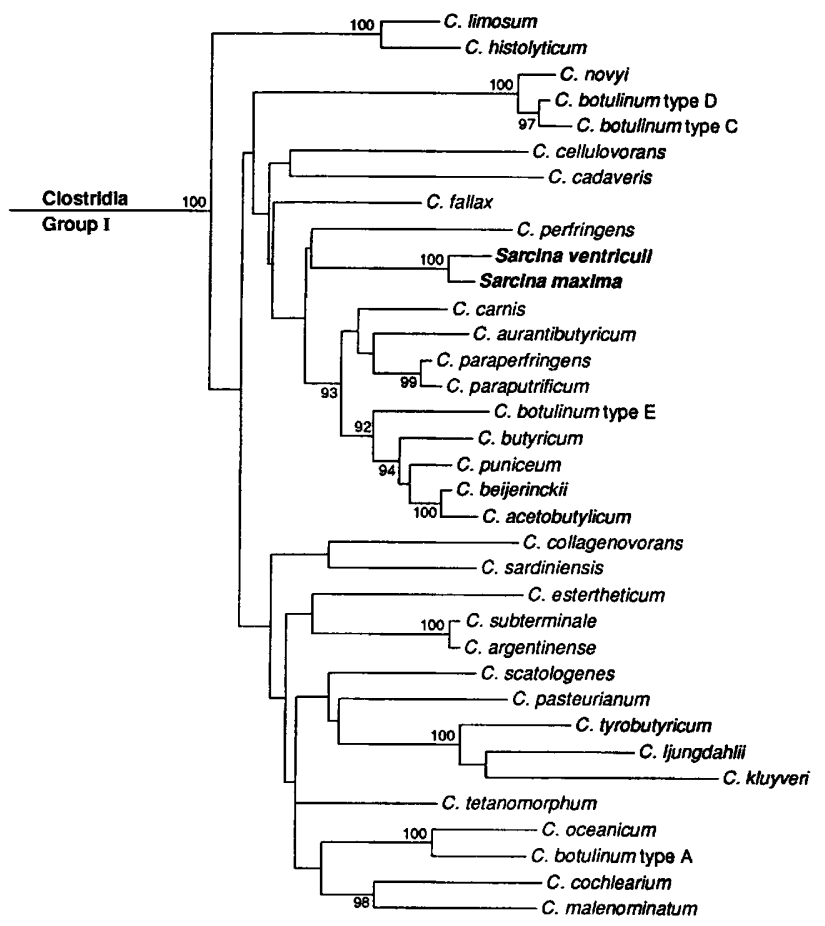

FIG. 1. Unrooted phylogenetic tree showing the positions of $S$. ventriculi and $S$. maxima within group I Clostridium. Bootstrap values greater than $90 \%$ are given at the branching points. 
TABLE 1 . Similarity values for the $16 \mathrm{~S}$ rRNA genes of Sarcina species and their closest relatives

\begin{tabular}{|c|c|c|c|c|c|c|c|c|c|c|c|c|}
\hline \multirow[b]{2}{*}{ Taxon } & \multirow[b]{2}{*}{$\begin{array}{c}\text { EMBL } \\
\text { accession } \\
\text { no. }\end{array}$} & \multicolumn{11}{|c|}{$\%$ Similarity with: } \\
\hline & & 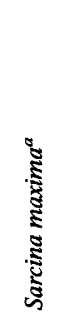 & 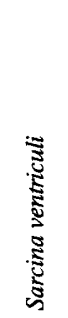 & 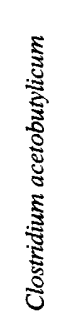 & 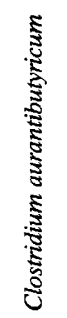 & 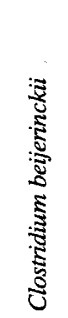 & 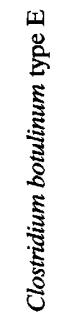 & 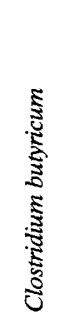 & 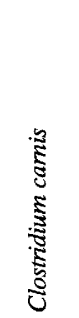 & 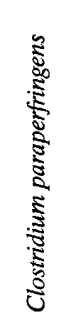 & 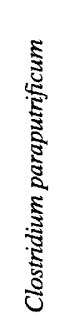 & 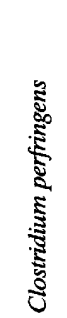 \\
\hline Sarcina ventriculi & X76649 & 98.5 & & & & & & & & & & \\
\hline Clostridium acetobutylicum & X68182 & 92.9 & 92.7 & & & & & & & & & \\
\hline Clostridium aurantibutyricum & X68183 & 92.9 & 92.3 & 95.9 & & & & & & & & \\
\hline Clostridium beijerinckii & X68179 & 93.0 & 93.1 & 99.2 & 95.8 & & & & & & & \\
\hline Clostridium botulinum type $\mathrm{E}$ & X68170 & 92.9 & 92.8 & 95.8 & 95.0 & 96.6 & & & & & & \\
\hline Clostridium butyricum & X68177 & 93.3 & 93.3 & 97.4 & 95.2 & 97.6 & 96.2 & & & & & \\
\hline Clostridium carnis & M59091 & 94.1 & 93.3 & 95.1 & 95.7 & 95.3 & 95.3 & 95.0 & & & & \\
\hline Clostridium paraperfringens & M59102 & 94.4 & 94.0 & 95.3 & 96.3 & 95.3 & 95.1 & 95.7 & 96.0 & & & \\
\hline Clostridium paraputrificum & X73445 & 93.9 & 93.8 & 95.3 & 97.1 & 95.9 & 95.8 & 96.0 & 96.4 & 98.8 & & \\
\hline Clostridium perfringens & M59103 & 93.3 & 93.3 & 93.4 & 92.8 & 93.6 & 93.5 & 93.0 & 94.2 & 93.8 & 93.8 & \\
\hline Clostridium puniceum & X73444 & 93.4 & 93.2 & 97.1 & 94.5 & 97.4 & 96.0 & 96.9 & 95.3 & 95.1 & 94.4 & 93.0 \\
\hline
\end{tabular}

${ }^{a}$ The EMBL accession number of $S$. maxima is $\mathrm{X} 76650$.

genetic tree (Fig. 1) was produced by using the NEIGHBOR, DNABOOT, and CONSENSE programs of the same package. The 16S rRNA gene sequences which we determined were deposited in the EMBL data library under accession numbers X76649 and X76650.

The partial 16S rRNA gene sequences of $S$. ventriculi and $S$. maxima consisted of 1,461 and 1,399 nucleotides, respectively, and exhibited $98.5 \%$ similarity (corresponding to 20 nucleotide differences). Sequence similarity calculations revealed that $S$. ventriculi and $S$. maxima were highly related to group I Clostridium of Johnson and Francis (13) (approximate 16S rRNA sequence similarity range, 89 to $94 \%$ ). The similarity values obtained with the closest relatives of both Sarcina species, as calculated by using the GAP program of the Genetics Computer Group package, are shown in Table 1. Significantly lower levels of sequence relatedness $(<85 \%)$ were obtained with other clostridial lineages (data not shown). The results of distance matrix analyses confirmed these affinities, with the two Sarcina species clustering well within the confines of this major Clostridium group (Fig. 1).

The genus Clostridium, as presently constituted, contains more than 100 species and is phylogenetically extremely heterogeneous. 16S rRNA sequencing has revealed that members of the genus Clostridium belong to several major lines of descent, some of which almost certainly represent new or distinct genera $(15,17,18)$. Almost one-half of all currently described clostridial species are members of a single clade, referred to as group I Clostridium of Johnson and Francis (13). The genus Clostridium is clearly in need of extensive taxonomic revision, and there is a growing view $(6,15)$ that group I Clostridium, which includes the type species, $C$. butyricum, could form the nucleus of a redefined genus. Restricting the genus Clostridium to the group I organisms would result in a genealogically coherent, albeit deep, genus and would do much to resolve the phylogenetic absurdity of the present system. Placement of $S$. ventriculi, the type species of the genus Sarcina, in group I Clostridium, however, presents a serious nomenclatural problem for any such future proposed generic emendation. The genus Sarcina (Goodsir) was proposed in
1842 (12) and as such has nomenclatural priority over the genus Clostridium (Prazmowski), which was described in 1880 (16). There is no question that nomenclatural rules are necessary and should be followed in most cases. However, strict adherence to nomenclatural priority would in this case result in the loss of the name Clostridium, with all Clostridium species becoming Sarcina species! Such a change would, in our opinion, be quite unacceptable to the scientific community, as the name Clostridium is widely used and the genus contains several important human and animal pathogens (e.g., Clostridium botulinum, Clostridium perfringens, and Clostridium tetani). Abandoning the name Clostridium also makes no phenotypic sense and would cause unnecessary confusion as clostridial species lack the typical parcel shape implied by the name Sarcina.

rRNA (or gene) sequencing is revolutionizing microbial systematics and provides an immensly powerful method for elucidating phylogenetic relationships. It is important that taxonomists capitalize on this revolution and do not shirk from constructing more phylogenetically meaningful classification schemes. As the results of rRNA sequence analysis fundamentally challenge many currently accepted classifications (including our perception of which phenotypic traits are good indicators of relatedness), a more pragmatic interpretation of the rules of priority may become necessary in order to minimize nomenclatural confusion. We believe that a more phylogenetically based classification of the clostridia is an achievable goal for the next few years, with the group I organisms forming the basis of a redefined genus Clostridium. From a purely practical point of view, we feel that if this occurs, the rule of priority should be set aside and Sarcina species should be included in an emended genus Clostridium. We therefore request an opinion from the Judicial Commission as to whether it would be an acceptable option to conserve the generic name Clostridium Prazmowski 1880 (type species, C. butyricum Prazmowski 1880).

After the submission of the manuscript for this paper, the rRNA gene sequence of $S$. ventriculi GIFU 7886 was published by Ezaki et al. (8). This sequence exhibits a level of similarity 
of $95.9 \%$ (corresponding to 54 base differences when 1,332 positions were compared) with the sequence of the $S$. ventriculi type strain. Ezaki et al. (8) included only one member of Clostridium group I (C. perfringens ATCC $13124^{\mathrm{T}}$ ) and therefore did not describe the precise genealogical placement of $S$. ventriculi within this major group.

We are grateful to the Ministry of Agriculture, Fisheries and Food for supporting this work

\section{REFERENCES}

1. Beijerinck, M. W. 1905. Een obligaat anaerobe gistingssarcine. Versl. Kon. Akad. Wetensch. Amsterdam 13:608-614.

2. Beijerinck, M. W. 1906. Une sarcine de fermentation anaerobie obligatoire. Arch. Neerl. Sci. Exact. Natur. Ser. 2 11:199-205.

3. Canale-Parola, E. 1970. Biology of the sugar-fermenting sarcinae. Bacteriol. Rev. 34:82-97.

4. Canale-Parola, E. 1974. Genus IV. Sarcina Goodsir 1842, p. 527-528. In R. E. Buchanan and N. E. Gibbons (ed.), Bergey's manual of determinative bacteriology, 8 th ed. The Williams and Wilkins Co., Baltimore.

5. Canale-Parole, E. 1986. Genus Sarcina Goodsir 1842, p. 11001103. In P. H. A. Sneath, N. S. Mair, M. E. Sharpe, and J. G. Holt (ed.), Bergey's manual of systematic bacteriology, vol. 2. Williams and Wilkins, Baltimore.

6. Cato, E. P., and E. Stackebrandt. 1989. Taxonomy and phylogeny, p. 1-22. In N. P. Minton and D. J. Clarke (ed.), Clostridia: biotechnology handbook, vol. 3. Plenum, London.

7. Devereux, J., P. Haeberli, and O. Smithies. 1984. A comprehensive set of sequence analysis programs for the VAX. Nucleic Acids Res. 12:387-395.

8. Ezaki, T., N. Li, Y. Hashimoto, H. Miura, and H. Yamamoto. 1994 $16 \mathrm{~S}$ ribosomal DNA sequences of anaerobic cocci and proposal of Ruminococcus hansenii comb. nov. and Ruminococcus productus comb. nov. Int. J. Syst. Bacteriol. 44:130-136.

9. Felsenstein, J. 1982. Numerical methods for inferring evolutionary trees. Q. Rev. Biol. 57:379-404.
10. Fox, G. E., K. J. Peckman, and C. R. Woese. 1977. Comparative cataloging of $16 \mathrm{~S}$ ribosomal ribonucleic acid: molecular approach to prokaryotic systematics. Int. J. Syst. Bacteriol. 27:44-57.

11. Fox, G. E., E. Stackebrandt, R. B. Hespell, J. Gibson, J. Maniloff, T. A. Dyer, R. S. Wolfe, W. E. Balch, R. S. Tanner, L. J. Magrum, L. B. Zablen, R. Blakemore, R. Gupta, L. Bonen, B. J. Lewis, D. A Stahl, K. R. Luehrsen, K. N. Chen, and C. R. Woese. 1980. The phylogeny of prokaryotes. Science 209:457-463.

12. Goodsir, J. 1842. History of a case in which a fluid periodically ejected from the stomach contained vegetable organisms of an undescribed form. With a chemical analysis of the fluid, by George Wilson. Edinb. Med. Surg. J. 57:430-443.

13. Johnson, J. L., and B. S. Francis. 1975. Taxonomy of the clostridia: ribosomal ribonucleic acid homologies among the species. J. Gen. Microbiol. 88:229-244.

14. Lawson, P. A., S. E. Gharbia, H. N. Shah, and D. R. Clark. 1989 Recognition of Fusobacterium nucleatum subgroups Fn-1, Fn-2 and Fn-3 by ribosomal RNA gene restriction patterns. FEMS Microbiol. Lett. 65:41-46.

15. Lawson, P. A., P. Llop-Perez, R. A. Hutson, H. Hippe, and M. D. Collins. 1993. Towards a phylogeny of the clostridia based on 16S rRNA sequences. FEMS Microbiol. Lett. 113:87-92.

16. Prazmowski, A. 1880. Untersuchung uber die Entwickelungsgeschichte und Fermentwirking einiger Bakterien-Arten. Inaugural Dissertation Hugo Voigt, Leipzig, Germany.

17. Rainey, F. A., and E. Stackebrandt. 1993. 16S rDNA analysis reveals phylogenetic diversity among the polysaccharolytic clostridia. FEMS Microbiol. Lett. 113:125-128.

18. Rainey, F. A., N. L. Ward, H. W. Morgan, R. Toalster, and E. Stackebrandt. 1993. Phylogenetic analysis of anaerobic thermophylic bacteria: aid for their reclassification. J. Bacteriol. 175: 4772-4779.

19. Willems, A., and M. D. Collins. 1992. Evidence for a close phylogenetic relationship between Afipia, the causal organism of cat scratch disease, Bradyrhizobium japonicum and Blastobacter denitrificans. FEMS Microbiol. Lett. 96:241-246.

20. Woese, C. R. 1987. Bacterial evolution. Microbiol. Rev. 51:221271. 